\title{
Effects of grazer and substrate amendments on nutrient and plankton dynamics in estuarine enclosures
}

\author{
Carolyn A. Miller*, Patricia M. Glibert, Gry Miné Berg, Margaret R. Mulholland \\ Horn Point Environmental Laboratory, Center for Estuarine and Environmental Studies, University of Maryland System, \\ PO Box 775, Cambridge, Maryland 21613, USA
}

\begin{abstract}
We compared the effects of substrate C:N ratio and macrozooplankton activity on nutrient and chlorophyll dynamics by amending the substrate $C: N$ ratios in carboys containing natural estuarine microplankton $(<200 \mu \mathrm{m}$ ) with additions of glucose (High $C: N$ ), arginine (Low $C: N$ ), or nothing (Control). Adult copepods (Acartia tonsa, 10 ind. $\mathrm{l}^{-1}$ ) were added to 1 carboy of each substrate treatment. Water and copepods were collected from the Choptank River, a subestuary of the Chesapeake Bay (USA) in August 1993. Ambient concentrations of $\mathrm{NH}_{4}{ }^{+}, \mathrm{NO}_{3}{ }^{-}$, and o- $\mathrm{PO}_{4}{ }^{3-}$ (orthophosphate) and dissolved primary amines (DPA) were all $<2.0 \mu \mathrm{g}$-at. $1^{-1}$ Dissolved and particulate nutrients and pigments were monitored over a $2 \mathrm{~d}$ period. In all carboys, plankton shifted from being net consumers of nutrients during the first 17 to $23 \mathrm{~h}$ (Phase 1) to being net regenerators afterwards (Phase 2). Chlorophyll concentrations declined and phaeopigments increased throughout the experiment. Both substrates stimulated microbial activity, as indicated by decreased accumulation of $0-\mathrm{PO}_{4}{ }^{3-}$ during Phase 2. increased accumulation of particulate carbon (PC) and nitrogen (PN) and increased chlorophyll loss during nughttime in the High $\mathrm{C}: \mathrm{N}$ and Low $\mathrm{C}: \mathrm{N}$ carboys relative to the Control carboy. In addition, the low $\mathrm{C}: \mathrm{N}$ substrate resulted in increased accumulations of $\mathrm{NH}_{4}{ }^{+}, \mathrm{NO}_{2}{ }^{-}$and $\mathrm{NO}_{3}{ }^{-}$; increased chlorophyll concentration; and a day/night pattern in chlorophyll concentration. Copepod additions resulted in greater PC, PN and chlorophyll losses and day/night patterns in chlorophyll concentration. The additions of copepods and substrates together resulted in several interactive effects, most notably, increased accumulations of $\mathrm{NH}_{4}{ }^{+}, \mathrm{O}_{-} \mathrm{PO}_{4}{ }^{3-}$, and, in the High C:N treatment, $\mathrm{NO}_{2}+\mathrm{NO}_{3}$, and greater chlorophyll, PC, and PN losses. Estimated rates of ingestion and excretion by the added copepods could not account for the observed changes in chlorophyll and nutrients, especially in the carboys with copepod and substrate additions, suggesting that the copepods increased nutrient regeneration and phytoplankton removal by microzooplankton.
\end{abstract}

KEY WORDS: Microbial loop - Substrate C:N ratios - Nutrient regeneration - Acartia tonsa Chlorophyll dynamics

\section{INTRODUCTION}

Grazing and nutrient availability are intimately linked in sustaining planktonic productivity when nutrient concentrations are low. Mesozooplankton (200 to $2000 \mu \mathrm{m}$ ) usually excrete a relatively minor proportion of the regenerated nutrients (e.g. Bidigare 1983). Despite this, mesozooplankton and larger animals can

\footnotetext{
•E-mail: cmiller@hpel.cees.edu
}

have important direct and indirect impacts on the species composition and metabolism of smaller organisms (Carpenter et al. 1987, Roman et al. 1988, Elser 1992, Glibert et al. 1992, Christaki \& Van Wambeke 1995). In particular, copepods, presumably through differential grazing or sloppy feeding, can greatly influence the degree to which bacterioplankton and microzooplankton regenerate $\mathrm{NH}_{4}{ }^{+}$(Roman et al. 1988, Glibert et al. 1992, Miller et al. 1995).

Bacterioplankton and microzooplankton $(<200 \mu \mathrm{m})$ usually play the quantitatively most important roles in 
regenerating $\mathrm{NH}_{4}{ }^{+}$(Caron \& Goldman 1990). The rate at which bacteria and microzooplankton supply $\mathrm{NH}_{4}{ }^{+}$ for phytoplankton, however, is itself subject to substrate limitation. Bacteria assimilate labile inorganic and organic dissolved substrates for growth and metabolism. The types and $\mathrm{C}: \mathrm{N}$ ratio of substrates available to bacterioplankton can control both the timing and magnitude of $\mathrm{NH}_{4}{ }^{+}$regeneration by this group of organisms (Goldman et al. 1987, Goldman \& Dennett 1991, Jørgensen et al. 1994). As mentioned above, the rates of nutrient regeneration by bacterioplankton and microzooplankton are also apparently affected by trophic interactions.

Experimentally, the substrate control of phytoplankton is usually studied by adding large amounts of nutrients (e.g. Koman et ai. 1988, Päul et al. 1995), Whon regenerated nutrients sustain productivity, however, nutrient availability to phytoplankton will usually be dominated by the factors which control nutrient regeneration by microheterotrophs, rather than large pulses of nutrients. Factors affecting nutrient regeneration include the quality of dissolved inorganic and organic substrates available to bacteria and the interactions between the microplankton and mesozooplankton. Thus, while there are several studies of plankton responses to nutrients or grazers that directly control phytoplankton biomass or growth, we are just beginning to study the more subtle aspects of how plankton assemblages respond to factors that control microheterotrophic regeneration of inorganic nutrients (e.g. Carlsson et al. 1995).

Temperate estuaries, such as the Chesapeake Bay (USA) and its tributaries, support seasonally high productivity at several trophic levels. Typically, both bacteria-and phytoplankton-based food webs are well developed. High phytoplankton biomass in the springtime is supported by high concentrations of riverborne nutrients. In the late summer, however, external inputs of inorganic nutrients are low and planktonic productivity depends on in situ regeneration of nutrients, nitrogen in particular, by both benthic and pelagic heterotrophs (Malone et al. 1988, 1991, Glibert et al. 1995). Summertime productivity in the Chesapeake Bay is intensely grazed by microzooplankton (White \& Roman 1992) which can in turn be consumed by mesozooplankton, such as the dominant copepod Acartia tonsa (Dolan. 1991, White \& Roman 1992). This intense grazing fuels the supply of nutrients via regeneration.

Here we investigated the effects of mesozooplankton and of the quality of dissolved substrates, alone and together, on the short-term nutrient and chlorophyll dynamics in a microplankton assemblage from a Chesapeake Bay tributary. We altered the abundance of the copepod, Acartia tonsa, predicting that the added copepods would result in increased $\mathrm{NH}_{4}{ }^{+}$con- centrations and decreased phytoplankton biomass Simultaneously, we altered the ambient $\mathrm{C}: \mathrm{N}$ ratios of dissolved substrates. We predicted that an organic substrate which was nitrogen-rich (substrate $\mathrm{C}: \mathrm{N}$ ratio $\leq 4)$ would result in increased concentrations of inorganic nitrogen $\left(\mathrm{NH}_{4}{ }^{+}, \mathrm{NO}_{3}{ }^{-}\right.$, and $\left.\mathrm{NO}_{2}{ }^{-}\right)$and increased phytoplankton biomass. Alternately, we hypothesized that a nitrogen-poor (substrate $\mathrm{C}: \mathrm{N}$ ratio $\geq 10$ ) organic substrate would not result in increased nutrient concentrations or chlorophyll biomass. Finally, while we expected the copepods and substrates to impact nutrient concentrations, we were uncertain of the net effect they would have in combination

\section{METHODS}

Water from the Choptank River, a subestuary of the Chesapeake Bay, was filtered through a $200 \mu \mathrm{m}$ sieve as it was dispensed into six $20 \mathrm{l}$ polyethylene Cubitainers ${ }^{\circledR}$ on September 2, 1993. The carboys were filled consecutively. The salinity was ca 8 ppt and the surface temperature was ca $28^{\circ} \mathrm{C}$. The carboys were kept in a constant-temperature room at $28^{\circ} \mathrm{C}$ with the lights turned on at 06:30 h and off at 20:00 h. Indirect red lighting was used during nighttime sampling. Carboys were gently aerated through $1 \mathrm{ml}$ disposable glass pipettes. Copepods used in the experiment were collected from the Choptank River on August 30, 1993, with a $200 \mu \mathrm{m}$ mesh net which had a $0.5 \mathrm{~m}$ diameter and a solid cod-end. Adult and C-5 Acartia tonsa were isolated, and maintained in an aerated, $8 \mathrm{l}$ carboy of 10 ppt Instant Ocean ${ }^{10}$ in the constant-temperature room. Natural 10 to $64 \mu \mathrm{m}$ particles sieved from the Choptank River water and cultured ciliates (Uronema marinum) were used as food for the copepods.

The carboys received 1 of 2 copepod treatments: with (+Copepods, target addition of 10 copepods $1^{-1}$ ) or without copepod additions. Carboys also received 1 of 3 substrate treatments: no addition (Control), an organic $C$-only addition (High $\mathrm{C}: \mathrm{N}$, target labile substrate $C: N \geq 10$ via glucose addition), or a low substrate $\mathrm{C}: \mathrm{N}$ addition (Low $\mathrm{C}: \mathrm{N}$, target labile substrate $\mathrm{C}: \mathrm{N} \leq 4$ via arginine addition). Immediately prior to the first sampling time, the appropriate number of copepods were rinsed with filtered seawater transfers, transferred to carboy water and divided into 3 aliquots, which were then added to the appropriate carboys. Finally, glucose and arginine were added to the carboys as necessary to achieve the target substrate $\mathrm{C}: \mathrm{N}$ ratios (Table 1)

Over the next $45 \mathrm{~h}$, we sampled each carboy 7 times for concentrations of dissolved and particulate materials (Table 2). At each sampling time, carboys were mixed by gentle inversion and $2 l$ of water was re- 
Table 1. Target and final substrate $\mathrm{C}: \mathrm{N}$ ratios, concentrations of ambient substrates, and substrate additions (in $\mu \mathrm{g}$-at. $\mathrm{C}$ or $\mathrm{N}^{-1}$ ) in experimental carboys

\begin{tabular}{|c|c|c|c|}
\hline & \multicolumn{3}{|c|}{$\begin{array}{l}\text { Substrate treatment } \\
\text { Control High C:N Low C:N }\end{array}$} \\
\hline Target labile C:N & - & $\geq 10$ & $\leq 4$ \\
\hline Ambient estimated labite DOC & 50 & 50 & 50 \\
\hline Ambient labile $\mathrm{N}^{b}$ & 0.6 & 0.6 & 0.6 \\
\hline DOC added & 0 & $6^{6}$ & $30^{\prime 1}$ \\
\hline DON added & 0 & 0 & $20^{j}$ \\
\hline Final estimated labile C:N & 83.3 & 93.3 & 3.9 \\
\hline \multicolumn{4}{|c|}{$\begin{array}{l}\text { "Assumed ambient DOC } 300 \mu \mathrm{g} \text {-at. } \mathrm{Cl}^{-1}, 10 \% \text { considered } \\
\text { labile (F. Shiah pers. comm.). To insure that additions } \\
\text { reached target ratios, we conservatively estimated labile } \\
\text { DOC concentrations as } 0 \text { and } 50 \mu \mathrm{g} \text {-at. }\left(\mathrm{I}^{-1} \text { for High C:N }\right. \\
\text { and Low C: } \mathrm{N}_{\text {treatments, respectively }} \\
\text { "As ambient } \mathrm{NH}_{4}{ }^{+} \text {, measured ca } 2 \mathrm{~h} \text { before experiment. } \\
\text { We assumed only } \mathrm{NH}_{4}{ }^{+}-\mathrm{N} \text { might be available to bacteria } \\
\text { in significant amounts; DPA concentrations are usually } \\
\text { ca } 0.5 \mu \mathrm{g} \text {-at. } \mathrm{Nl}^{-1} \text {. See text for discussion of other forms of } \\
\text { ambient DON } \\
\text { 'As glucose } \\
\text { "As arginine }\end{array}$} \\
\hline
\end{tabular}

moved. This mixing and the aeration prevented oxygen depletion and a disproportionate accumulation of detritus over the course of the experiment, as was confirmed by PC:PN (particulate carbon:particulate nitrogen) ratios near Redfield values at the end of the experiment. The water was sampled for concentrations of dissolved and particulate material (Table 2). Samples from carboys containing copepods were prefiltered through a $183 \mu \mathrm{m}$ mesh sieve. Particulate material was collected on combusted Whatman GF/F glass fiber filters and the filtrates were used for nutrient and total dissolved nitrogen (TDN) analyses. Samples for dissolved primary amines (DPA) were filtered through $0.22 \mu \mathrm{m}$ pore sterilized Acrodisc ${ }^{\circledR}$ filters. All samples were frozen for later analysis. Here we discuss the treatment effects which were larger than the analytical errors of the measurements (Table 1).

\section{RESULTS}

\section{Nutrient dynamics}

The first 17 to $24 \mathrm{~h}$ in all the carboys was generally a period of net nutrient consumption, while the remainder of the experiment was to a greater extent a period of nutrient regeneration. For convenience, we refer to these 2 periods as Phase 1 and Phase 2, respectively. The timing and magnitude of these changes in individual carboys, though, depended upon the substrate and copepod additions and the interaction of the two.
Table 2. Parameters measured and methods used for measurements. Analytical variabılity, as $95 \%$ C.l.'s for replicate samples at representatıve concentrations (see figures): inorganic nutrients, $\leq 2 \%$; DPA. 2 to $6 \%$; prgments, $4 \%$ PC and PN, $10 \%$

\begin{tabular}{|c|c|}
\hline Parameter & Technique \\
\hline $\mathrm{NH}_{4}{ }^{+}$ & Manual colorimetry (Parsons et al. 1984) \\
\hline $\mathrm{NO}_{2}$ & Manual colorimetry (Parsons et al. 1984) \\
\hline $\mathrm{NO}_{3}^{-}$ & $\begin{array}{l}\text { Automated colorimetry for } \mathrm{NO}_{3}^{-}+\mathrm{NO}_{2}^{-} \\
\text {corrected for } \mathrm{NO}_{2}^{-} \text {(Parsons et al. 1984) }\end{array}$ \\
\hline $\mathrm{O}-\mathrm{PO}_{4}{ }^{3}$ & $\begin{array}{l}\text { Automated colorimetry (Parsons et al. } \\
\text { 1984) }\end{array}$ \\
\hline DPA & $\begin{array}{l}\text { Manual fluorometry, glycine standard } \\
\text { (Parsons et al. 1984) }\end{array}$ \\
\hline $\begin{array}{l}\text { Chlorophyll, } \\
\text { phaeopigments }\end{array}$ & Manual fluorometry (Parsons et al. 1984) \\
\hline $\begin{array}{l}\text { Particulate } \\
\text { carbon and } \\
\text { nitrogen }\end{array}$ & $\begin{array}{l}\text { Automated combustion and } \\
\text { gas analysis, Control Equipment } \\
440 \text { CHN Analyzer }\end{array}$ \\
\hline
\end{tabular}

During Phase 1, in the Control and High C:N carboys, $\mathrm{NH}_{4}{ }^{+}$declined from an initial concentration of $0.4-1.9 \mu \mathrm{g}$-at. $\mathrm{l}^{-1}$ to about $0.1 \mu \mathrm{g}$-at. $\mathrm{l}^{-1}$; DPA decreased from about $0.4-0.7 \mu \mathrm{g}$-at. $\mathrm{l}^{-1}$ to about $0.3 \mu \mathrm{g}$-at. $\mathrm{l}^{-1}$ (Figs. $1 \mathrm{~A}, \mathrm{~B}, \mathrm{D}, \mathrm{E} \& 2 \mathrm{~A}, \mathrm{~B}$ ); and $\mathrm{o}-\mathrm{PO}_{4}{ }^{3-}$ declined from about $0.5 \mu \mathrm{g}$-at. $\mathrm{I}^{-1}$ to a minimum of about $0.4 \mu \mathrm{g}$-at. $\mathrm{I}^{-1}$ (Fig. 2C). Variability in nutrient concentrations at $0 \mathrm{~h}$

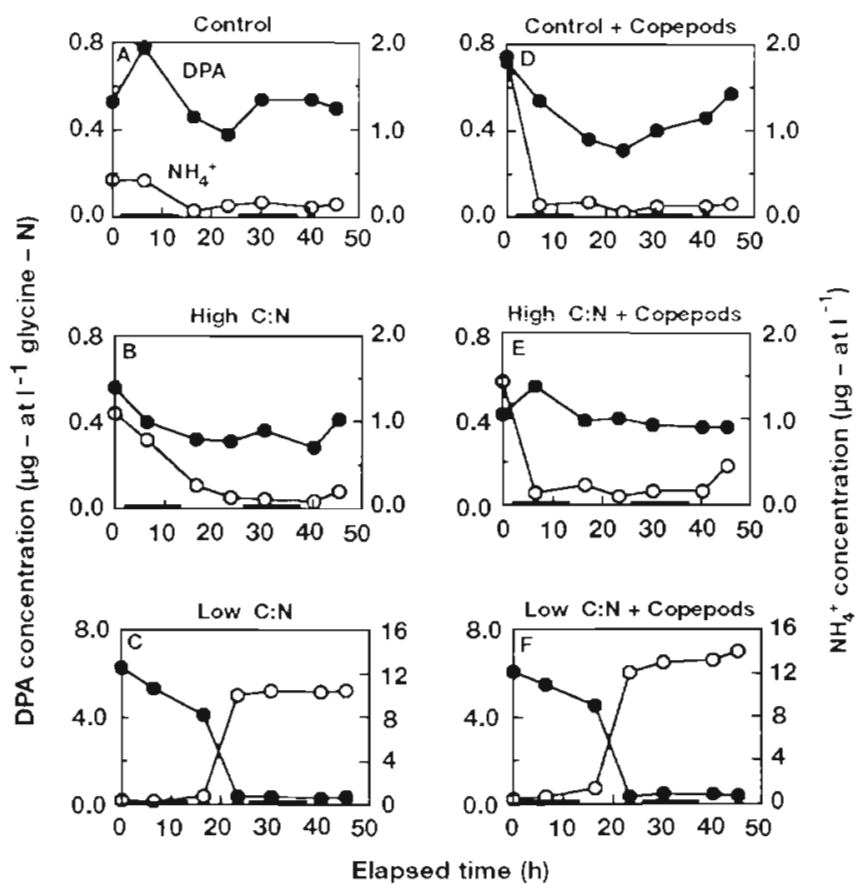

Fig. 1. Concentrations of $\mathrm{NH}_{4}{ }^{+}$and DPA in the carboys during the experiment. Note scale change for Low $C: N$ carboys Black bars indicate when lights were off 

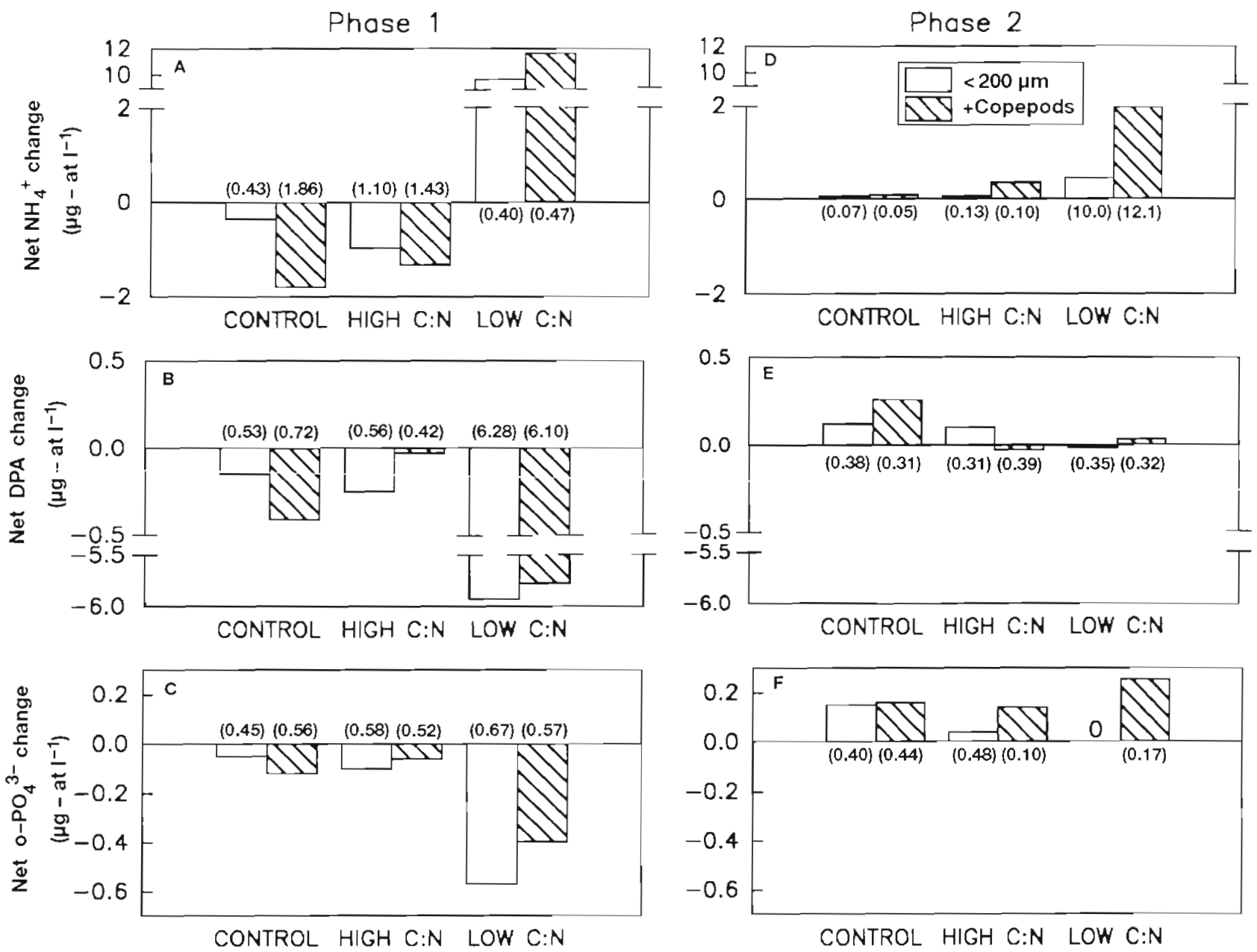

Fig. 2. Net changes in concentrations of $\mathrm{NH}_{4}{ }^{*}, \mathrm{DPA}$, and $\mathrm{o}-\mathrm{PO}_{4}{ }^{3-}$ during Phase 1 and Phase 2. Phases were separated by the sampling time at which a nutrient reached a minimum (maximum for $\mathrm{NH}_{4}{ }^{+}$in Low $\mathrm{C}: \mathrm{N}$ treatment) at 18 or $23 \mathrm{~h}$. Numbers in parentheses indicate concentrations at beginning of phase

was likely due to variability in the source water. In the Low $\mathrm{C}: \mathrm{N}$ carboys, $\mathrm{NH}_{4}{ }^{+}$concentrations increased slightly during the first $17 \mathrm{~h}$ as DPA and $0-\mathrm{PO}_{4}{ }^{3-}$ concentrations decreased (Fig, 1C, F). There was then a pronounced transition between 17 and $23 \mathrm{~h}$, when the concentrations of $\mathrm{NH}_{4}{ }^{+}, \mathrm{DPA}$, and $0-\mathrm{PO}_{4}{ }^{3-}$ changed most quickly. Concentrations of DPA and $0-\mathrm{PO}_{4}{ }^{3-}$ declined to 0.3 and $0.1 \mu \mathrm{g}$-at. $\mathrm{l}^{-1}$, respectively, while the concentration of $\mathrm{NH}_{4}{ }^{+}$increased from about 1 to about $1.1 \mu$ g-at. $\mathrm{l}^{-1}$ (Figs. 1C, F \& 2A, B, C). About $15 \%$ more $\mathrm{NH}_{4}{ }^{+}$accumulated in the Low $\mathrm{C}: \mathrm{N}+$ Copepods carboy than in the Low $C: N$ carboy during this time (Fig. 2A).

The net changes in nutrient concentrations during Phase 2 were particularly sensitive to the substrate and copepod treatments. Often there was a strong interaction between the 2 types of treatments. Net $\mathrm{NH}_{4}{ }^{+}$ accumulation after $23 \mathrm{~h}$ was highest in the Low C:N+ Copepods carboy and decreased in the order Low
$\mathrm{C}: \mathrm{N}+$ Copepods $>$ Low $\mathrm{C}: \mathrm{N}>$ High $\mathrm{C}: \mathrm{N}+$ Copepods carboys (Fig. 2D). The net accumulations of $0-\mathrm{PO}_{4}{ }^{3-}$ and DPA during Phase 2 were influenced in an opposite manner by substrate and copepod additions. In the absence of copepod additions, the net accumulations of both were highest in the Control carboy, followed by the High C:N, then Low C:N carboys (Fig. 2E, F). In the +Copepods carboys, net DPA accumulation was highest in the Control treatment (Fig. 2E). Net o- $\mathrm{PO}_{4}{ }^{3-}$ accumulation in the +Copepods treatment was highest in the Low C:N+Copepods carboy and surpassed that in the carboys without added copepods only in the presence of substrate additions (Fig. 2F).

There was little net change over the $2 \mathrm{~d}$ in $\mathrm{NO}_{2}{ }^{-}$concentrations in the Control, Control+Copepods, and High $\mathrm{C}: \mathrm{N}$ carboys (Fig. $3 \mathrm{~A}, \mathrm{C}$ ). In contrast, $\mathrm{NO}_{2}^{-}$and $\mathrm{NO}_{3}$ concentrations increased in the High $\mathrm{C}: \mathrm{N}+\mathrm{Copepods}$ during Phase 2, and in the Low $\mathrm{C}: \mathrm{N}$ and Low $\mathrm{C}: \mathrm{N}+$ Copepods carboys throughout the experiment (Fig. 3). 

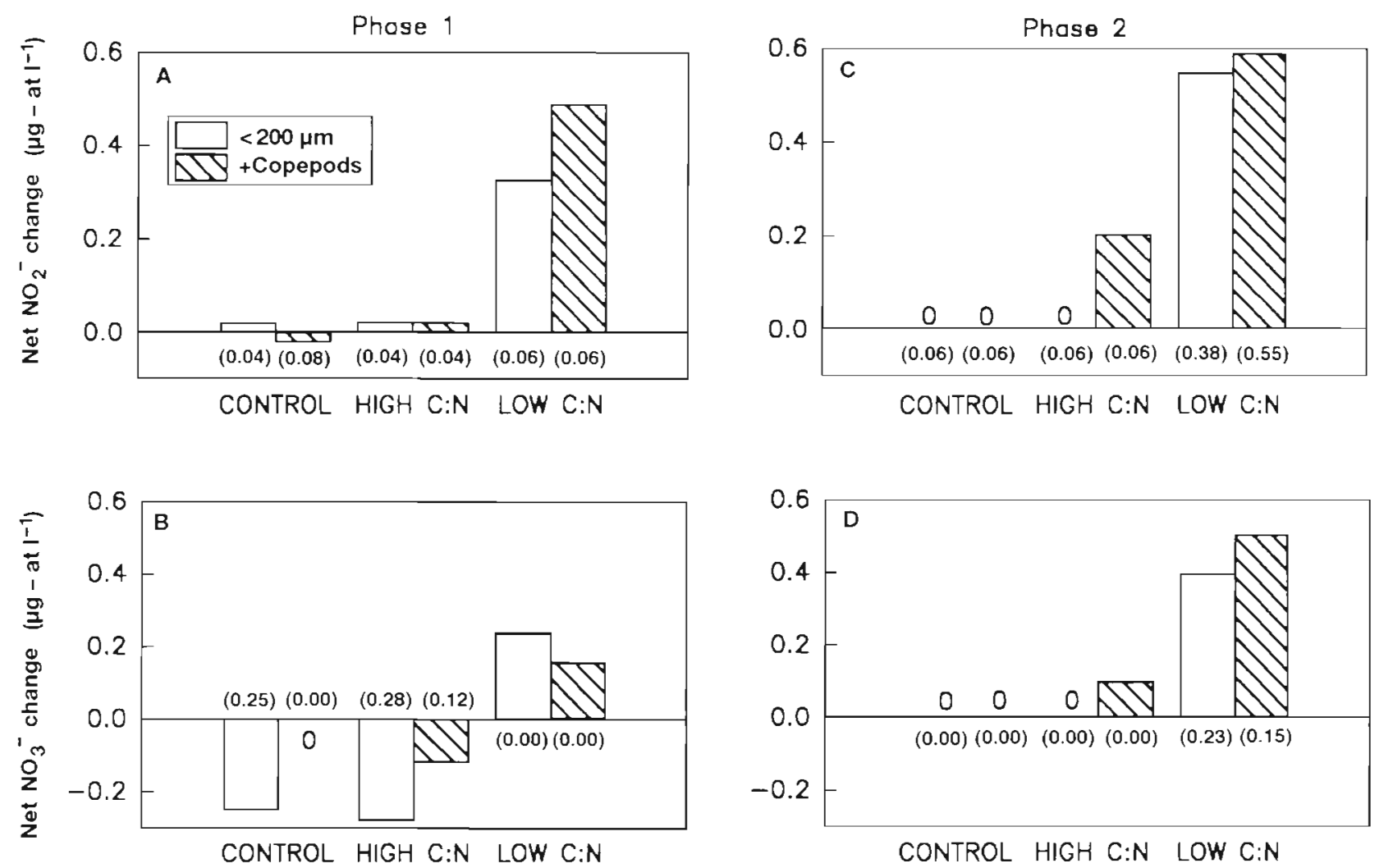

Fig. 3. Net changes in concentrations of $\mathrm{NO}_{2}{ }^{-}$and $\mathrm{NO}_{3}{ }^{-}$during Phase 1 and Phase 2. Phases separated at $23 \mathrm{~h}$. Numbers in parentheses indicate concentrations at beginning of phase

The mean DIN (dissolved inorganic nitrogen, $\mathrm{NH}_{4}{ }^{+}+\mathrm{NO}_{2}^{-}+\mathrm{NO}_{3}^{-}$):DIP (dissolved inorganic phosphorus) ratios were about 1 during Phase 1 in all carboys, except in the Low $\mathrm{C}: \mathrm{N}+$ Copepods carboy, where $\mathrm{NH}_{4}{ }^{+}$regeneration had already begun and the mean ratio was about 2 (Fig. 4A). During Phase 2 mean ratios decreased to below 1 in the Control, Control+Copepods and High C:N carboys (Fig. 4B) due to decreased DIN concentrations and increased DIP concentrations. The ratio decreased slightly less in the High $\mathrm{C}: \mathrm{N}+\mathrm{Copepods}$ carboy due to higher $\mathrm{NO}_{2}^{-}$concentrations in that carboy. The DIN:DIP ratios increased during Phase 2 to about 100 in the Low $\mathrm{C}: \mathrm{N}$ carboy, and to about 50 in the Low $\mathrm{C}: \mathrm{N}+$ Copepods carboy, where $\mathrm{O}-\mathrm{PO}_{4}{ }^{3-}$ concentrations were higher (Fig. 4B).
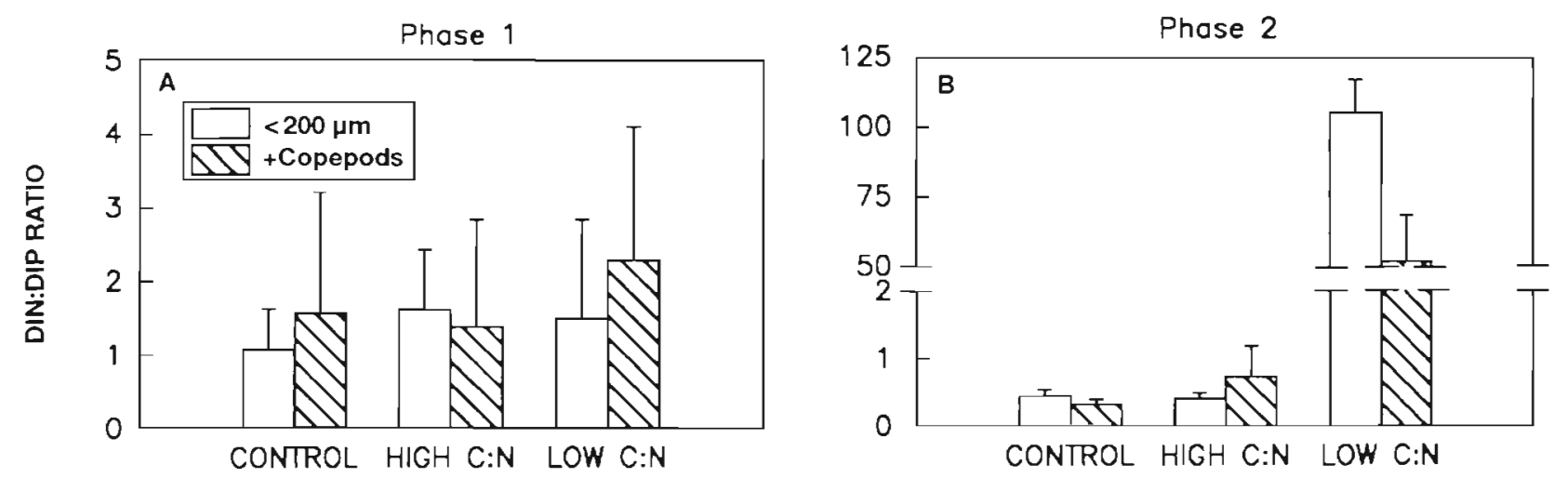

Fig. 4. Mean DIN:DIP ratios (+1 SD) in the carboys during Phase $1(n=3)$ and Phase $2(n=4)$. Phase 1 values for 0 to 17 ; Phase 2 values for 23 to $45 \mathrm{~h}$ 


\section{Dynamics of $\mathrm{PC}, \mathrm{PN}$ and pigments}

Initial PC and PN concentrations were about $110 \mu \mathrm{g}$ at. $\mathrm{C}^{-1}$ and $16 \mu \mathrm{g}$-at. $\mathrm{N}^{-1}$ in all carboys (Fig. 5A, B) Due to lower accumulations of $\mathrm{PC}$ and $\mathrm{PN}$ during Phase 1, and higher losses during Phase 2, the +Copepods carboys had relatively lower PN and PC concentrations than their counterparts without copepod additions by the end of the experiment (Fig. 5C, D), significantly so in the case of $P N(p<0.05$, paired $t$-test for the difference in final PN concentrations in carboys with vs without copepod additions within each treatment). A relatively large change also occurred in the Low C:N carboy, where PC increased to nearly $140 \mu \mathrm{g}$ at. $\mathrm{C} \mathrm{l}^{-1}$ and $\mathrm{PN}$ increased to nearly $25 \mu \mathrm{g}$-at. $\mathrm{N}^{-1}$ during Pllase 1, resultiog in a net increase of PN and PC in that carboy. The mean PC:PN ratios varied little; mean atomic PC:PN ratios ranged from 6.3 (Low $C: N+C o p e-$ pods) to 6.8 (High $\mathrm{C}: \mathrm{N}$ ) during Phase 1 and 5.9 (Low C:N) to 6.9 (High C:N) during Phase 2.

Chlorophyll concentrations generally increased or remained constant during the first daylight period, then decreased over the course of the experiment while phaeopigment concentrations increased throughout the experiment, regardless of treatment (Fig. 6). However, the magnitude of the net chlorophyll change
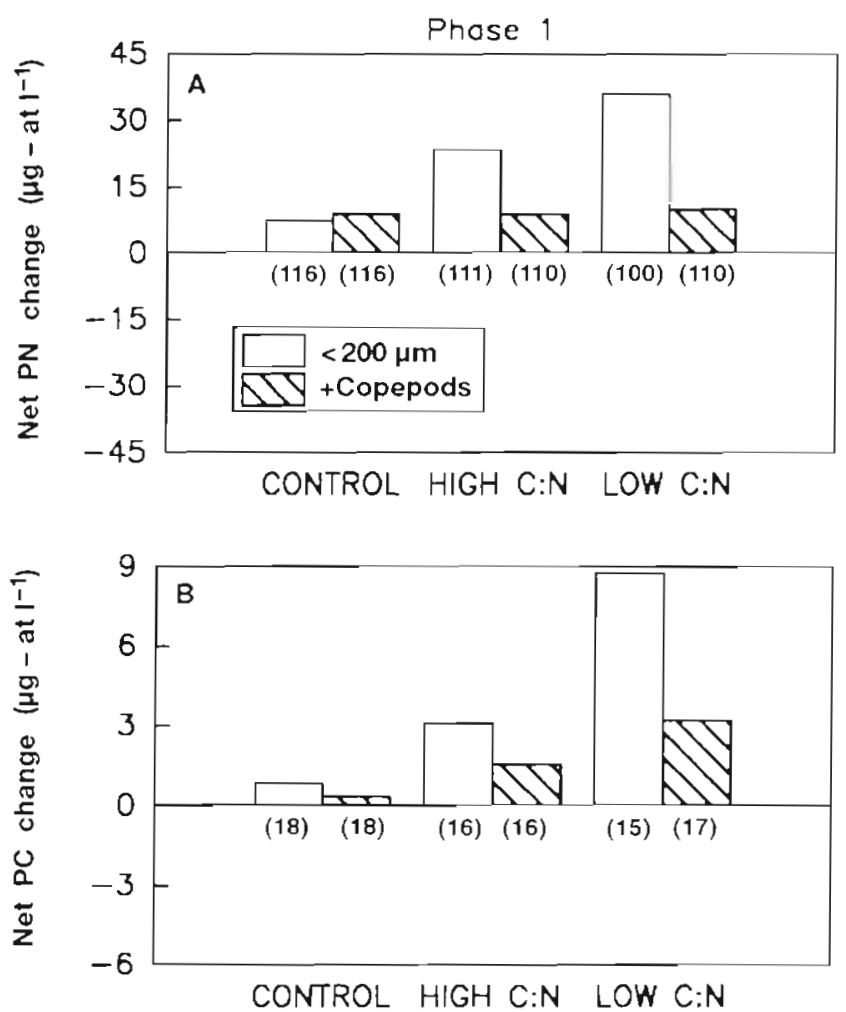

was related to both the copepod abundance and substrate amendments. The net chlorophyll loss was smallest in the Low C:N carboy (Fig. 7A). Net chlorophyll losses in the High $\mathrm{C}: \mathrm{N}+$ Copepods and Low $\mathrm{C}: \mathrm{N}+\mathrm{Copepods}$ carboys were higher than in their counterparts without copepods (Fig. 7A). Net phaeopigment accumulation in the carboys without copepods was similar across treatments (Fig. 7B), but additional phaeopigment accumulation in the +Copepods carboys was highest in the Low $\mathrm{C}: \mathrm{N}$ treatment and decreased in the order Low C:N treatment $>$ Control treatment $>$ High $\mathrm{C}: \mathrm{N}$ treatment (Fig. 7B). The final chlorophyll concentration in the Low $\mathrm{C}: \mathrm{N}$ carboy was about $60 \%$ higher than in the other 5 carboys (10.9 vs $6.70 \pm 0.86 \mu \mathrm{g} \mathrm{l}^{-1}$, mean $\pm 95 \% \mathrm{Cl}_{;} \mathrm{p}<0.01$, $t$-test of final chlorophyll concentration in Low C:N carboy vs mean of final chlorophyll concentrations of all other carboys). Conversely, the final phaeopigment concentration in the Low $\mathrm{C}: \mathrm{N}+\mathrm{Copepods}$ carboy was significantly ( $p<0.05$, comparison as above) higher than in the other 5 carboys.

Chlorophyll concentrations fluctuated on a day/night basis in all +Copepods carboys and in the Low C:N carboy without added copepods (Fig. 6). Nighttime chlorophyll losses occurred to some degree in all carboys, but the losses increased with the addition of both substrates
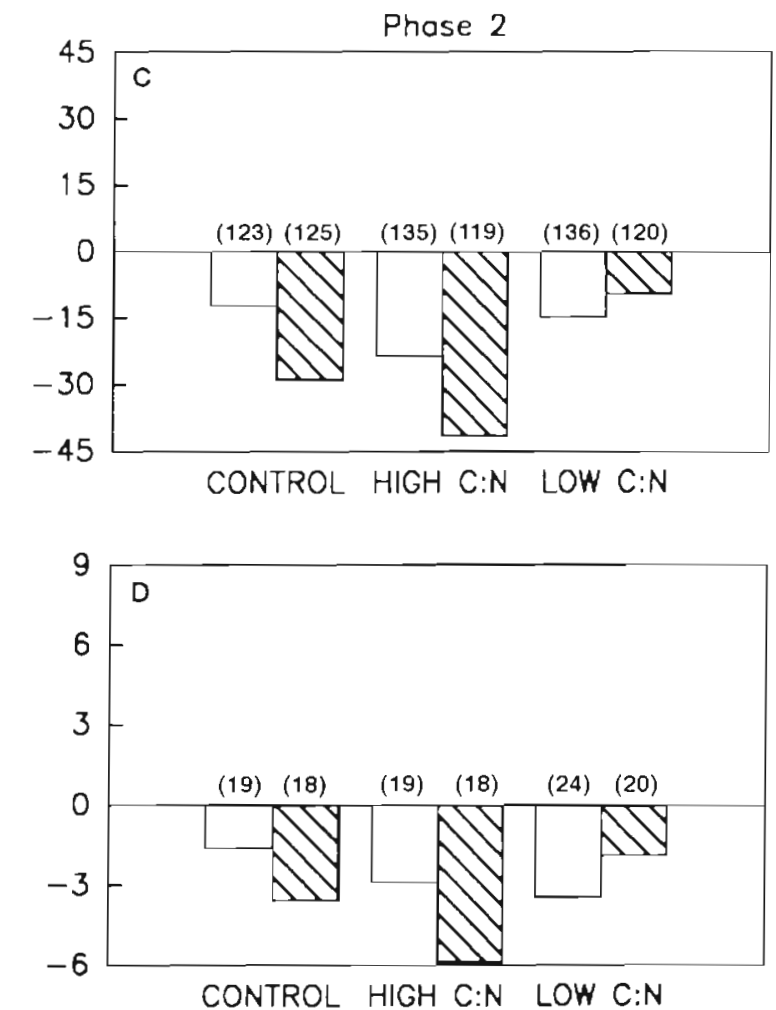

Fig. 5. Net changes in PC and PN concentrations during Phase 1 and Phase 2. Phases separated at $23 \mathrm{~h}$ (High C:N at $30 \mathrm{~h}$ ). Numbers in parentheses indicate concentrations at beginning of phase 


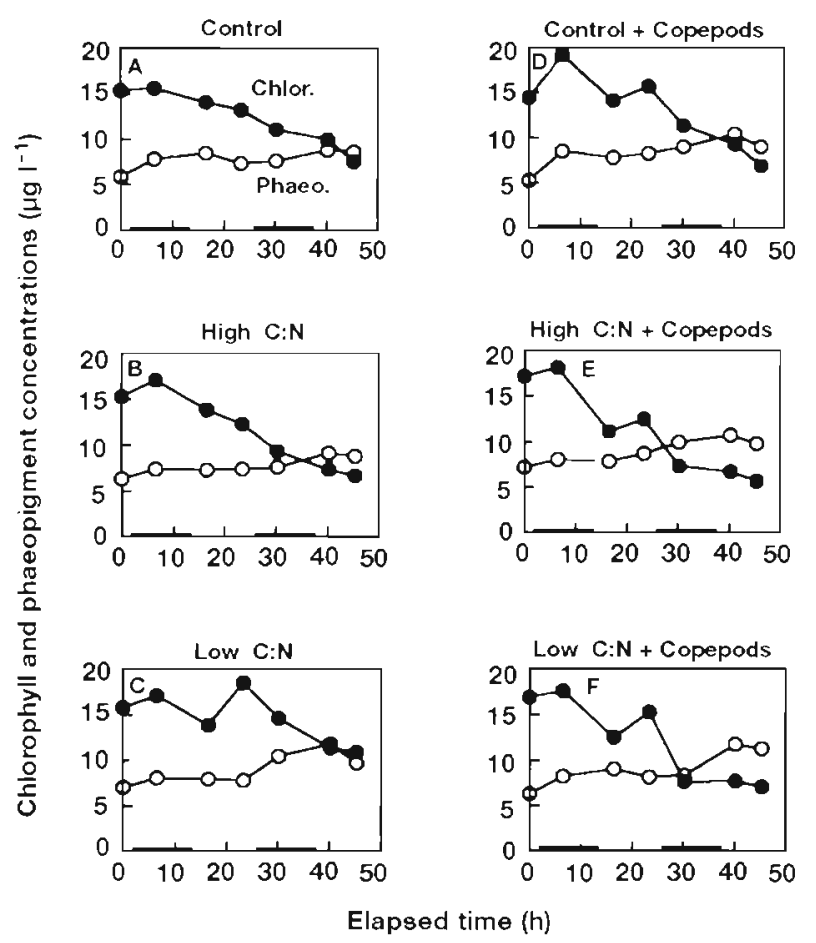

Fig. 6. Concentrations of chlorophyll and phaeopigment in the carboys during the experiment. Black bars indicate when lights were off

(Fig. $7 \mathrm{C}$ ). Chlorophyll losses during the nighttime hours were about $0.35 \mathrm{\mu g} \mathrm{h}^{-1}$ faster in the +Copepods carboys than in the corresponding carboys without copepods, regardless of the substrate treatment (Fig. 7C).

\section{DISCUSSION}

In this experiment our measurements focused on bulk changes in nutrient and particulate concentrations. Changes in these parameters in such closed systems are due to changes in either the number of organisms (i.e. biomass), organism-specific metabolic rates, or some combination of the two. While we do not have data on community composition, the biomass and nutrient data that we do have are strongly indicative of certain processes.

The plankton assemblage we sampled appeared to be highly dependent on a tight coupling between nitrogen regeneration and uptake, which is typical of summertime plankton assemblages in Chesapeake Bay. The PC:PN ratios were at the Redfield ratio and both $\mathrm{NH}_{4}{ }^{+}$and $\mathrm{o}-\mathrm{PO}_{4}{ }^{3-}$ were measurable, indicating that the phytoplankton were nitrogen-sufficient. The DIN:DIP ratios, on the other hand, were well below the Redfield ratio of 16 required for balanced growth, suggesting that nitrogen availability might limit phytoplankton growth. We could have underestimated the
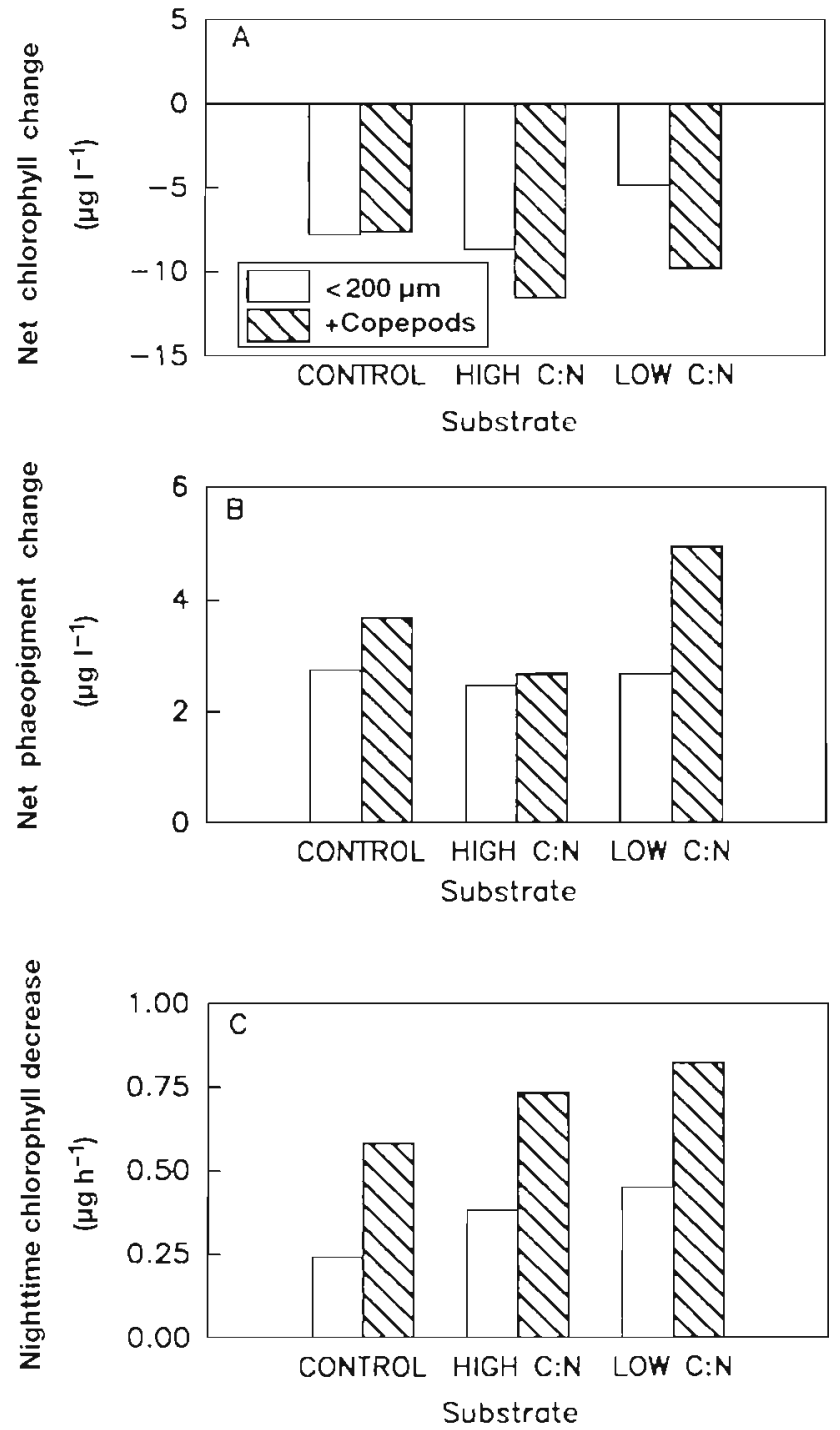

Fig. 7. Net changes in (A) chlorophyll and (B) phaeopigment concentrations over the course of the entire experiment and (C) mean rates of decrease of chlorophyll concentration during 2 nighttime periods ( 7 to $17 \mathrm{~h}$ and 23 to $30 \mathrm{~h}$ )

total amount of nitrogen available to phytoplankton, by only including inorganic sources of nitrogen in our estimate of available nitrogen, but it is unlikely that other types of nitrogen available to phytoplankton, such as urea, were plentiful enough (ca $7 \mu$-at. $\mathrm{N}^{-1}$ ) to increase the ratio to one of balanced growth. Therefore, nitrogen regeneration was likely occurring and phytoplankton were likely to be particularly sensitive to factors affecting nutrient regeneration.

\section{Grazer effects}

Copepod additions consistently resulted in increased chlorophyll accumulation during the day and increased 
chlorophyll loss at night. In the absence of added substrates (Control treatment) these 2 processes balanced each other and thus there were no effects by copepods alone on the net chlorophyll concentration (Figs. 6A, D \& 7A). Copepods often eat more during the night and their presence in enclosures can result in higher phytoplankton biomass than in enclosures with only microplankton (e.g. Roman et al. 1988, Christaki \& Van Wambeke 1995), but resultant day/night differences in chlorophyll concentrations are not always observed. Increases in phytoplankton biomass on such a short time scale can be due to reduced grazing or increased availability of nutrients in the presence of copepods. Although both come into play to a certain extent, the importance of increased nutrient availability is supported by previous research showing that Acartia tonsa densities of 10 ind. $\mathrm{l}^{-1}$ stimulate $\mathrm{NH}_{4}{ }^{+}$release on the scale of hours (Glibert et al. 1992), and by the fact that the same day/night pattern occurred in the nutrient-replete Low C:N carboy (Fig. 6C). The 10 adult $A$. tonsa $\mathrm{I}^{-1}$ that we added to the carboys in this experiment is higher than the typical summertime densities of adults in Chesapeake Bay. Such densities have been reported from other estuaries (Ambler et al. 1985), however, and in Chesapeake Bay the densities of adult plus subadult $A$. tonsa together can easily exceed 10 copepods $\mathrm{l}^{-1}$ (Roman et al. 1993).

\section{Substrate effects}

In the Low $\mathrm{C}: \mathrm{N}$ treatment, we manipulated the substrate $C: N$ ratio by adding an amino acid which has been shown to support bacterial nitrogen regeneration (Goldman et al. 1987). Rapid decreases in amino acid concentrations and increases in $\mathrm{NH}_{4}{ }^{+}$concentrations after a 15 to 20 h lag have been observed in cultures of marine bacteria after experimental manipulations of substrate C:N ratios (Goldman et al, 1987, Goldman \& Dennett 1991, Jørgensen et al. 1994). The present results demonstrate that a low $\mathrm{C}: \mathrm{N}$ addition to intact microplankton assemblages also results in the uptake of DPA and the regeneration of $\mathrm{NH}_{4}{ }^{+}$after a lag period.

Bacterial regeneration of $\mathrm{NH}_{4}{ }^{+}$is not only a function of substrate $\mathrm{C}: \mathrm{N}$ ratio, but also depends on the specific substrates available. When low substrate $\mathrm{C}: \mathrm{N}$ ratios are achieved with combinations of glucose, $\mathrm{NH}_{4}{ }^{+}$, and amino acids, little or no $\mathrm{NH}_{4}{ }^{+}$is regenerated (Goldman et al. 1987, Goldman \& Dennett 1991, Jørgensen et al. 1994), indicating that bacteria regenerate significant amounts of $\mathrm{NH}_{4}{ }^{+}$only when labile DON (dissolved organic nitrogen) is the nitrogen source and when DOC (dissolved organic carbon) has become limiting (Goldman \& Dennett 1991). The rapid appearance of 50 to $60 \%$ of the added substrate as $\mathrm{NH}_{4}{ }^{+}$(Fig. 1) sug- gests that this might have been the case in our Low $\mathrm{C}: \mathrm{N}$ carboys. Alternatively, $\mathrm{NH}_{4}^{+}$regeneration could have been due to bacterial growth which was subsequently grazed and catabolized by bacterivores. The rapid changes in nutrient concentration consistent with those observed in bacterial cultures, however, suggest that the nutrient dynamics observed between 17 and $23 \mathrm{~h}$ were due to bacterial processes. Regardless of the nutritional status of the bacteria, or even the group of organisms responsible for regenerating it, the $\mathrm{NH}_{4}^{+}$ regenerated could and did support increased phytoplankton biomass and bacterial nitrification in the Low C:N treatment.

While dramatic $\mathrm{NH}_{4}{ }^{+}$regeneration occurred only in the Low C:N carboys, there is evidence that the high $\mathrm{C}: \mathrm{N}$ substrate might have stimulated microbial processes also. Glucose additions have previously been shown to stimulate bacterial productivity, and, sometimes, bacterial density in estuarine and mesohaline waters (Chin-Leo \& Benner 1992, Shiah \& Ducklow 1994). Likewise the addition of high C:N (ca 56) humic material to large mesohaline cylinders resulted in increased bacterial density and productivity (Carlsson et al. 1995). In our experiment, the High C:N carboy had higher accumulations of $\mathrm{PC}$ and $\mathrm{PN}$ during Phase 1 (Fig. 5) and lower accumulations of $\mathrm{O}-\mathrm{PO}_{4}{ }^{3-}$ during Phase 2 (Fig. 2F) than the Control carboy did, and other changes suggestive of increased herbivory (discussed below). We hypothesize that the ambient o- $\mathrm{PO}_{4}{ }^{3-}$ was taken up by bacteria along with the labile glucose we added. Nitrogen was available to the bacteria in the High $\mathrm{C}: \mathrm{N}$ treatment in the form of ambient $\mathrm{NH}_{4}{ }^{+}$and DPA. In addition, dissolved combined amino acids (DCAA) can occur in relatively high amounts (6 $4 \mathrm{~mol} \mathrm{l^{-1 }}$; Coffin 1989) and can be a significant nitrogen source for estuarine bacteria (Coffin 1989, Jørgensen et al. 1994, Kroer et al. 1994). Interestingly, the actual availability of ambient DCAA might have been influenced by our experimental treatment: bacterial uptake of ambient DCAA can be stimulated by the addition of labile substrates with relatively high $\mathrm{C}: \mathrm{N}$ ratios (10 and 15; Jørgensen et al. 1994).

In addition to influencing nutrient dynamics, the substrate additions might also have influenced herbivory, even in carboys without added adult copepods. The higher losses of PC and PN during Phase 2 (Fig. 5) and higher rates of chlorophyll disappearance during the nights (Fig. 7C) in both the High C:N and Low C:N carboys relative to the Control carboy suggest that the substrate additions resulted in a greater degree of nighttime herbivory by some group or groups of microzooplankton, presumably $<200 \mu \mathrm{m}$ copepodites, which were abundant during this experiment. Microzooplankton densities, along with those of phytoplankton and bacteria, have previously been observed to in- 
crease with additions of high $\mathrm{C}: \mathrm{N}$ humic substances (Carlsson et al. 1995). Results such as these demonstrate how the substrate supply to bacteria can indirectly influence higher order trophic interactions.

\section{Interactive effects}

The combined effects produced by the substratecopepods treatments (Table 3 ) demonstrate some ways in which grazing and substrate supply interact in intact plankton assemblages. The accumulations of $\mathrm{NH}_{4}^{+}$, o- $\mathrm{PO}_{4}{ }^{3-}$ (Fig. 2D, F), and $\mathrm{NO}_{2}{ }^{-}+\mathrm{NO}_{3}{ }^{-}$(Fig. 3C, D) during Phase 2 were higher in the carboys with both copepod and substrate additions than in the corresponding carboys with only substrate additions. There were also larger net changes in PC, PN (Fig. 5), and chlorophyll (Fig. $7 \mathrm{~A}, \mathrm{~B}$ ) in the +Copepods carboys in the High $\mathrm{C}: \mathrm{N}$ and Low $\mathrm{C}: \mathrm{N}$ treatments than in the Control treatment. Thus copepods quickly modify the degree to which nutrients are sequestered into biomass.

Copepods can directly increase nutrient concentrations via the release of metabolic products. The nutrient increases we observed, however, were larger than those expected by copepod nutrient release alone. We estimate that the added Acartia tonsa released 0.12 to $0.18 \mu \mathrm{g}$-at. $\mathrm{NH}_{4}^{+} \mathrm{l}^{-1}, 0.03 \mu \mathrm{g}$-at. DPA ${ }^{-1}$, and $0.004 \mu \mathrm{g}$-at. $0-\mathrm{PO}_{4}{ }^{3-} \mathrm{I}^{-1}$ during the experiment [rates of $\mathrm{NH}_{4}{ }^{+}$and DPA release estimated from rates for $A$. tonsa collected from Chesapeake Bay in August (Miller 1992); rates of o- $\mathrm{PO}_{4}{ }^{3-}$ excretion calculated by weight ratio (lkeda 1985)]. These estimates are lower than the accumulations of $\mathrm{NH}_{4}{ }^{+}$and $\mathrm{o}-\mathrm{PO}_{4}{ }^{3-}$ in the + Copepods carboys with substrate additions and the DPA accumulation in the Control+Copepods carboy during Phase 2 (Fig, 2D, E, F). Consistent with our results, $\mathrm{NH}_{4}^{+}$accumulation in another enclosure experiment also exceeded that expected from copepod release rates (Roman et al. 1988). Copepods can indirectly stimulate $\mathrm{NH}_{4}{ }^{+}$regeneration by bacteria or microzooplankton through their release of DON during feeding and metabolism (Roman et al. 1988, Glibert et al. 1992) or trophic interactions with larger microzooplankton (Miller et al. 1995) and we hypothesize that the increased nutrient release observed in this experiment was in part due to these types of interactions. Furthermore, the accumulation of $\mathrm{NO}_{2}^{-}$and $\mathrm{NO}_{3}{ }^{-}$in the High $\mathrm{C}: \mathrm{N}+$ Copepods carboy, relative to the High $\mathrm{C}: \mathrm{N}$ carboy, also points to an indirect role for copepods.
Copepods do not release $\mathrm{NO}_{2}{ }^{-}$or $\mathrm{NO}_{3}{ }^{-}$themselves, but they do release $\mathrm{NH}_{4}{ }^{+}$and organic compounds, which are the substrates for bacterial nitrification. Nitrification occurred in a previous carboy experiment in carboys without added copepods, but with relatively high $\mathrm{NH}_{4}{ }^{+}$ concentrations (Bronk \& Glibert 1993). That, together with our observations of $\mathrm{NO}_{3}{ }^{-}$and $\mathrm{NO}_{2}^{-}$accumulation only in the High $\mathrm{C}: \mathrm{N}$ carboy with copepods, suggests that the $\mathrm{NH}_{4}{ }^{+}$regeneration enhanced by the copepods is what stimulated nitrification in that carboy. Copepods, then, can modify both the amount and type of regenerated nutrients available to phytoplankton and bacteria. This might explain to some degree why the addition of high $\mathrm{C}: \mathrm{N}$ humic substances, together with the addition of copepods, to mesohaline cylinders resulted in higher bacterial, phytoplankton, and microzooplankton densities, even in the absence of nutrient accumulation (Carlsson et al. 1995). In that experiment, however, copepods were added to all cylinders, so grazer effects could not be separated from substrate effects.

Likewise, copepods can directly remove particulate material via ingestion. Again, the differences in changes in particulate $\mathrm{N}$ and $\mathrm{C}$ concentrations between carboys with and without copepods are larger than those estimated based on copepod ingestion rates. In these experiments, the additional net carbon loss in the +Copepods carboys represents ingestion rates of about 9, 20, and $13 \mu \mathrm{g} \mathrm{C}$ copepod ${ }^{-1} \mathrm{~d}^{-1}$ in the Control, High $C: N$, and Low C:N treatments, respectively. Similarly, the additional net loss of chlorophyll in the +Copepods carboys represents respective rates of 0,15 , and $18 \mu \mathrm{g}$ $C$ copepod ${ }^{-1} \mathrm{~d}^{-1}$, calculated using $C$ :chlorophyll ratios from our $t_{0}$ data. Rates of ingestion of phytoplankton for Acartia tonsa in Chesapeake Bay in September are about $5 \mu \mathrm{g} \mathrm{C}$ copepod ${ }^{-1} \mathrm{~d}^{-1}$, although a rate of about $9 \mu \mathrm{g} \mathrm{C} \mathrm{d}^{-1}$ has been measured in July (White \& Roman 1992). Our chlorophyll-based rates are subject to error in the C:chlorophyll ratio, but together with those cal-

Table 3. Summary of the major substrate, copepod, and interactive effects on nutrient and particulate dynamics in experimental carboys.,+- : increase or decrease relative to the Control carboys

Substrate-only effects

Both substrates

- Phase 2 o- $\mathrm{PO}_{4}{ }^{3-}$ accumulation

+ Net PC and PN accumulation

+ Nighttime chlorophyll loss

Low C:N addition only

+ Phase $10-\mathrm{PO}_{4}{ }^{3-}$ loss

+ Phase $2 \mathrm{NH}_{4}^{+}$accumulation

- Phase 2 DPA accumulation

+ Phase 2 DIN:DIP

+ Net $\mathrm{NO}_{2}^{-}+\mathrm{NO}_{3}{ }^{-}$accumulation

+ Net chlorophyll accumulation

+ Daytime chlorophyll accumulation

\section{Copepod-only effects}

+ Daytime chlorophyll accumulation

+ Nighttime chlorophyll loss

- Net phaeopigment accumulation

- Net PC and PN accumulation

Interactive (substrate + copepods) effects + Phase $2 \mathrm{NH}_{4}{ }^{+}$and $0-\mathrm{PO}_{4}{ }^{3-}$ accumulation

- Phase 2 DPA accumulation

$+\mathrm{NO}_{2}^{-}+\mathrm{NO}_{3}^{-}$concentrations (High $\mathrm{C}: \mathrm{N}$ )

- Net chlorophyll, PN/PC accumulation 
culated from carbon loss, they point to an additional sink for carbon. We suggest that copepod-microzooplankton interactions, such as trophic cascading within multiple trophic levels of microzooplankton or resource competition, resulted in enhanced microzooplankton grazing on phytoplankton, especially in the carboys amended with both copepods and substrates. It is also possible that copepod ingestion increased in response to higher food quality (Houde \& Roman 1987. Cowles et al. 1988) in the carboys with substrate additions, but whether the increased chlorophyll removal in the carboys with both substrate and copepod additions was due to direct or indirect activities of the copepods, it supports our hypothesis that both substrates stimulated microplankton processes.

The interactive effects of substratc quality and trophic control on phytoplankton dynamics have often been studied by examining the relative impacts of inorganic nutrients versus those of herbivores. Here we added organic substrates selected to modify bacterial uptake and regeneration of nutrients, and thus indirectly regulate nutrient availability to phytoplankton. Our Low C:N treatment resulted in a large input of $\mathrm{NH}_{4}{ }^{+}$after a time lag. The impacts of copepods on phytoplankton were both positive (increased nutrient regeneration) and negative (increased grazing). The results of our High $\mathrm{C}: \mathrm{N}$ treatment suggest that through increased microbial activity and trophic interactions between microplankton and copepods, additions of high C:N substrates can also provide regenerated nutrients for primary production. Thus it is essential to know the composition and inputs of dissolved organic matter in estuaries, not only to understand how microbial processes are controlled, but also to understand how estuarine food-webs are controlled.

Acknowledgements. This work was supported by NSF grant OCE 91-16251 to P.M.G. and EPA Multiscale Experiment Ecosystem Research Center Project \#R819640. J. Ludlam Jr and the Analytical Services Laboratory at HPEL assisted with sample analysis. We thank T Kana, M. Roman, D. Conley, and the Environmental Education Program for use of equipment; F.-K. Shiah for advice during experimental design; $C$. Fan, M. Lomas, J. Ludlam Jr, M. O'Donahue, and several reviewers for their comments on the manuscript; and the maintenance staff at Horn Point Environmental Laboratory for their help with the constant-temperature room. This is contribution number 2792 from the Center for Environmental and Estuarine Studies.

\section{LITERATURE CITED}

Ambler JW, Cloern JE, Hutchinson A (1985) Seasonal cycles of zooplankton from San Francisco Bay. Hydrobiologia $129: 177-197$

Bidigare RR (1983) Nitrogen excretion by marine zooplankton. In: Carpenter EJ, Capone DG (eds) Nitrogen in the marine environment. Academic Press, New York, p 385-409
Bronk DA, Glibert PM (1993) Contrasting patterns of dissolved organic nitrogen release by two size fractions of estuarine plankton during a period of rapid $\mathrm{NH}_{4}{ }^{*}$ consumption and $\mathrm{NO}_{2}{ }^{-}$production. Mar Ecol Prog Ser 96.291-299

Carlsson P, Graneli E, Tester P, Boni L (1995) Influences of riverine humic substances on bacteria, protozoa, phytoplankton, and copepods in a coastal plankton community Mar Ecol Prog Ser 127:213-221.

Caron DA, Goldman JC (1990) Protozoan nutrient regeneration. In: Capriulo GM (ed) Ecology of marine protozoa Oxford University Press, New York, p 283-306

Carpenter SR, Kitchell JF, Hodgson JR, Cochran PA, Elser JJ, Elser MM, Lodge DM, Kretchmer D, He X, von Ende CN (1987) Regulation of lake primary productivity by food web structure. Ecology 68:1863-1876

Chin-Leo G, Benner R (1992) Enhanced bacterioplankton production and respiration at intermediate salinities in the Mississippi River plume. Mar Ecol Prog Ser 87:87-103

Christaki U, Van Wambeke F (1995) Simulated phytoplankton bloom input in top-down manipulated microcosms: comparative effect of zooflagellates, ciliates and copepods. Aquat Microb Ecol 9:137-147

Coffin RB (1989) Bacterial uptake of dissolved free and combined amino acids in estuarine waters. Limnol Oceanogr 34:531-542

Cowles TJ, Olson RJ, Chisholm SW (1988) Food selection by copepods: discrimination on the basis of food quality. Mar Biol 100:41-49

Dolan JR (1991) Microphagous ciliates in mesohaline Chesapeake Bay waters: estimates of growth rates and consumption by copepods. Mar Biol 111:303-309

Elser JJ (1992) Phytoplankton dynamics and the role of grazers in Castle Lake, California. Ecology 73:887-902

Glibert PM, Conley DJ, Fisher TR, Harding LW Jr, Malone TC (1995) Dynamics of the 1990 winter/spring bloom in Chesapeake Bay. Mar Ecol Prog Ser 122:27-43

Glibert PM, Miller CA, Garside C, Roman MR, McManus GB (1992) $\mathrm{NH}_{4}{ }^{+}$regeneration and grazing: intordependent processes in size-fractionated ${ }^{15} \mathrm{NH}_{4}{ }^{+}$experiments. Mar Ecol Prog Ser 82:65-74

Goldman JC, Caron DA, Dennett MR (1987) Regulation of gross growth efficiency and ammonium regeneration in bacteria by substrate C:N ratio. Limnol Oceanogr 32:1239-1252

Goldman IC, Dennett MR (1991) Ammonium regeneration and carbon utilization by marine bacteria grown on mixed substrates. Mar Biol 109:369-378

Houde SE, Roman MR (1987) Effects of food quality on the functional ingestion response of the copepod Acartia tonsa. Mar Ecol Prog Ser 40:69-77

Ikeda $T$ (1985) Metabolic rates of epipelagic marine zooplankton as a function of body mass and temperature. Mar Biol 85:1-11

Jorgensen NOG, Kroer N, Coffin RB (1994) Utilization of dissolved nitrogen by heterotrophic bacterioplankton: effect of substrate C:N ratio. Appl Environ Microbiol 60: $4124-4133$

Kroer N, Jørgensen NOG, Coffin RB (1994) Utilization of dissolved nitrogen by heterotrophic bacterioplankton: a comparison of three ecosystems. Appl Environ Microbiol 60 4116-4123

Malone TC, Crocker LH, Pike SE, Wendler BW (1988) Influences of river flow on the dynamics of phytoplankton production in a partially stratified estuary. Mar Ecol Prog Ser 48:235-249

Malone TC, Ducklow HW, Peele ER, Pike SE (1991) Picoplankton carbon flux in Chesapeake Bay. Mar Ecol Prog Ser 78:11-22 
Miller CA (1992) Effects of food quality and quantity on nitrogen excretion by the copepod, Acartia tonsa. PhD dissertation, University of Maryland, College Park

Miller CA, Penry DL. Glibert PM (1995) The impact of trophic interactions on rates of nitrogen regeneration and grazing in Chesapeake Bay. Limnol Oceanogr 40: $1005-1011$

Parsons TR, Maita Y, Lalli CM (1984) A manual of chemical and biological methods for seawater analysis. Pergamon Press, Oxford

Paul AJ, Leavitt PR, Schindler DW, Hardie AK (1995) Direct and indirect effects of predation by a calanoid copepod (subgenus: Hesperodiaptomus) and of nutrients in a fishless alpine lake. Can J Fish Aquat Sci 52:2628-2638

Responsible Subject Editor: J. Dolan, Villefranche-sur-Mer, France
Roman MR, Ducklow HW, Fuhrman JA, Garside C, Glibert PM, Malone TC, MCManus GB (1988) Production, consumption, and nutrient cycling in a laboratory mesocosm. Mar Ecol Prog Ser 42:39-52

Roman MR, Gauzens AL, Rhinehart WK, White JR (1993) Effects of low oxygen waters on Chesapeake Bay zooplankton. Limnol Oceanogr 38: 1603-1614

Shiah FW, Ducklow HW (1994) Temperature and substrate regulation of bacterial abundance, production and specific growth rate in Chesapeake Bay, USA. Mar Ecol Prog Ser 103:297-308

White JR, Roman MR (1992) Seasonal study of grazıng by metazoan zooplankton in the mesohaline Chesapeake Bay. Mar Ecol Prog Ser 86:251-261

Manuscript first received: March 19, 1996

Revised version accepted: February 9, 1997 